INTERNATIONAL JOURNAL OF MULTIDISCIPLINARY RESEARCH AND ANALYSIS

ISSN(print): 2643-9840, ISSN(online): 2643-9875

Volume 04 Issue 11 November 2021

DOI: 10.47191/ijmra/v4-i11-41, Impact Factor: 6.072

Page No.- 1732-1742

\title{
Comprehensive Assessment of The Regional Potential Investment of The Republic of Uzbekistan
}

\author{
Otajanov Umid Abdullaevich \\ PhD, Tashkent State University of Economics
}

\begin{abstract}
ANNOTATION: The article describes the views of scientists and the authour's approach regarding role of regions' potential socioeconomic in country's development and investment climate in the regions in attracting investment. In addition to the traditional method of assessing the investment climate, the author initially conducted a descriptive analysis, which in turn allows for complete information and clear conclusions on the distribution of investments in the regions. Also, as an author's approach, a methodology for assessing the investment climate in the regions on the basis of a comprehensive assessment is presented, which is assessed taking into account the specific features and capabilities of the regions of the Republic of Uzbekistan.
\end{abstract}

KEYWORDS: investment, innovation, investment activity, environmental attractiveness, budget and financial potential, generalized integral indicator

\section{INTRODUCTION}

At present, in the context of the ongoing pandemic around the world, it is important to attract investment and its effective use in the development and stability of the country's economy. In this regard, it is necessary to anticipate problems such as the unprofitability of investments in the world economy or to limit the full capacity of the production process due to underestimation of the risks and dangers of effective use of investments, to develop science-based measures to eliminate disparities in regional development ensuring their sustainable growth, achieving global competitiveness - requires an in-depth and comprehensive analysis of the factors affecting investment efficiency, the identification of quantitative links between them.

The degree of environmental attractiveness in the regions depends on a system of many factors, which is determined by the influence of an infinite number of factors. Especially for the comparison of regional investments, the investment environment in each of the regions can be characterized by a certain number of quantitative measures - synthetic or generalized. On the other hand, the investment climate of the region can not be quantified by any measure - this type of attempt is misguided and can lead to ignoring this complex phenomenon.

At the same time, in the context of the information explosion experienced by modern civilization, it has become an important issue today to realize that in the real materials of science, great attention must be paid to the directional methods. Therefore, in terms of practical application of the selected methodology, its efficiency, accuracy and reliability are required to match its characteristics as any other method.

\section{LITERATURE REVIEW}

Samuel Bjorklund, Tobias Ulin [1] on the analysis of investment valuation, financial time series forecasting and investment portfolio optimization, investment and utilization issues and evaluation of investment projects, T. Kokhonen [2], neural network methodology for forecasting and estimating financial time series was developed by Howard B Demuth, Mark H Beale [3], P.Samuelson [4], G.Alexander, J.Bayle [5], Lawrence J.Gitman, Michael D.Jonk [6] and K.R. McConnell [7] conducted investment processes, risk, optimization, and forecasting under conditions of uncertainty.

In the CIS countries Yu.P.Zaychenko [8], I.Z.Batyrshin [9], S.V.Aksenov, V.B.Novoseltsev [10], V.V.Kruglov, V.V.Borisov [11] developed methods and technologies for the application of neural network models and hybrid systems in the conditions of uncertainty in research, EA Trofimova, VL Mazdurov, DV Gilyov, AB Barsky [12] on the management and decision-making of the practical economy developed a methodology for solving using neural networks, I. Grishina [13] contributed to the methodology of complex analysis of investment processes in the regions, G.B. Polish [14] and Vladimir Glontillar [15] assess the state of the 


\section{Comprehensive Assessment of The Regional Potential Investment of The Republic of Uzbekistan}

regional budget with absolute and relative balance indicators for the effectiveness of fiscal policy, budget deficit and public debt, theoretical aspects of investment flow management in individual sectors, including investment in industrial development who have worked on problems of access.

\section{RESEARCH METHODOLOGY}

Based on the results of the study, the following system was used to assess the investment climate of the regions based on the use of classification algorithms in different categories of symptom space, which are inefficient due to the size of the space or can be applied only on one of the measurement scales (quantitative or nominal):

1. a measure of investment attractiveness $-\left(I^{a}\right)$;

2. (the investment potential of the region $-\left(I_{r}^{p}\right)$;

3. Investment Risk Scale $-\left(I^{R}\right)$;

4. investment activity in the region- $(Y)$;

5. Effective use of the region's investment potential $\left(E_{I}^{p}=Y / I_{r}^{p}\right)$;

6. Effectiveness of the territory's investment attractiveness $\left(E_{I}^{a}=Y / I^{a}\right)$.

To determine the integral level of investment potential $I_{r}^{p}$ of the region, the characteristics of production and financial potential in the region (volume and rate of change in industrial output, level of small business development, share of profitable enterprises, total domestic investment resources, retail sales, export potential, number of enterprises and organizations), characteristics of social potential in the region (availability of cars and telephones, roads and railways, paid services, living standards), as well as characteristics of natural and geographical potential of the region (natural resources of mineral resources, and their geographical location relative to foreign trade routes).

Since all specific indicators of investment attractiveness have different dimensions and dimensions, it is necessary to make them unique for comparison, that is, according to the standardization procedure, they are done by determining the average value of each specific indicator of a particular region across the country:

$$
I_{\text {sit }}^{a}=\frac{I_{\text {sit }}^{*}}{I_{s t}}
$$

here, $I_{\text {sit }}^{*}-t$ - year (or other time period) $i$ - by region $s$ The numerical value of the private indicator,

$I_{s t}-t$ - The average of the numerical value of the s s private indicator in the country,

$I_{\text {sit }}^{a}$ - in $t$ is the standardized value of the s chi private indicator for the i-region.

As a result, all regional indicators are converted to standardized regional indicators $\left(I_{\text {sit }}^{a}\right)$ are converted, i.e., dimensionless relative values that describe the ratio of the numerical values of each indicator to the numerical value in the country. Each standardized indicator across the country will have a value that is equally equal together.

$i$ - the investment attractiveness of the region $t$ - Integral calculation of the year $\left(l_{i t}\right)$ is performed according to a two-stage multidimensional average formula.

In the first stage, a set of specially standardized regional indicators will be converted into two integral indicators - an overall indicator of investment potential $\left(I_{i t}^{p}\right)$ - specific indicators depending on the factors that make up the investment potential of the region $\left(I_{\text {sit }}^{p}\right)$ and an overall indicator of investment risk $\left(I_{i t}^{R}\right)$ - integration of specific indicators related to the factors of formation of regional non-profit investment risks $\left(I_{\text {sit }}^{R}\right)[13]$.

$i$ - investment potential of the region $t$ - in $\left(I_{i t}^{R}\right)$ The general indicator of the level of risk is calculated according to the following formula:

$$
I_{i t}^{p}=\frac{\sum_{s=1}^{n} I_{s i t}^{p} \cdot k_{s t}^{p}}{\sum_{s=1}^{n} k_{i t}^{p}}
$$

here, $I_{i t}^{p}-t$ - year (or other time period) $i$ - the numerical value of the standardized s-specific indicator of investment potential in the region;

$k_{s t}^{p}$ - weighted coefficient of meaningfulness of s-specific indicator in t-th year of investment potential;

$n$ - the number of standardized specific indicators that depend on the factors that shape the integral level of investment potential of the regions.

The next step in determining the attractiveness of the investment climate of the region is to determine the innovative potential of the regions, which requires the calculation of relative values of aggregate indicators. Considering the variation of a number of factors in this regard, it can be determined using the following formula:

$$
I_{\text {H.K }}=\frac{I_{a b s}}{I_{\text {base }}}
$$

Here: $I_{\text {н.қ }}$ - relative value of the indicator, \%; 


\section{Comprehensive Assessment of The Regional Potential Investment of The Republic of Uzbekistan}

$I_{a b s}-$ the absolute value of the indicator;

$I_{\text {base }}$ - the base value of the indicator.

In each case, different parameters (GRP - gross regional product, etc.) are basic ( $\left.I_{\text {base }}\right)$ which allows them to increase the absolute value of the indicators used in a comparable form. Thus, it is advisable that we use the number of people employed in the region. In particular, 11, 12, 13, .., In are the main indicators. For a comprehensive assessment of the innovative potential of the regions, it is appropriate to use a group of integrated indicators, in which all $n$ key indicators are divided as the $n$-th root of the geometric mean product.

$$
N_{1}=\sqrt[n]{I_{i 1}+I_{i 2}+\cdots+I_{i n}}
$$

An integrated assessment of innovation potential allows us to bring different sets of indicators into a single generalized indicator and compare the innovative potential of regions and assess the innovative potential of a region not only by the sum of its components, but also their complex and multifaceted interdependence. The advantage of these proposed integrated indicators is that it covers all the key innovation potential and its components in a comparable form. In the proposed methodology, group integral indicators are considered equivalent. It is therefore a generalized integral indicator of the region's innovation potential $\mathrm{N}_{i}$ $(m=5)$ values are determined by summing:

here: $G_{i . i}$ - generalized integral index;

$$
G_{i . i}=\sum_{i=1}^{m} N_{i}
$$

$\mathrm{i}$ - the number of integral indicators of the group.

Regional investment risk $\left(I^{R}\right)$ In order to determine the level of integration, it is necessary to take into account the following indicators of low-income population, unemployment, environmental pollution, climate inconvenience and political stability, which are difficult to take into account in the study. Therefore, in assessing the level of risk in the study, it is advisable to take into account the level of indebtedness for taxes and budget payments, which reflects the consumer price index and the level of fin ancial risk in the region.

I. In order to assess the investment attractiveness of the region, it is necessary to determine another indicator, namely the budget and financial capacity, which will increase the return on investment and interest of investors in the region. Therefore, taking into account that the level of stability of the regional budget is determined by the amount of resources required to ensure a minimum budget stability, we cite four types of budget stability:

1. Absolutely stable state of the budget, which can be characterized by the following correlation: $P m<D_{x}+D_{t}$

here $\mathrm{Pm}$ - minimum budget expenditures, $\mathrm{D}_{\mathrm{x}}$ - private budget revenues, $\mathrm{D}_{\mathrm{T}}$ - regulatory revenues of the budget.

2. Normal situation: $P m=D_{x}+D_{T}$

3. Unstable condition: $P m=D_{x}+D_{T}+I d$. (4)

here: Id - additional resources to reduce budget stress (e.g., extra-budgetary funds, loans, etc.).

4. Crisis situation: $P m>D_{x}+D_{T}+I d$.

It should be noted that the proposed method of assessing the stability of the regional budget is not universal, as it does not take into account significant differences in the revenues of regional governments. The same goes for minimal costs. Correlations can change under the influence of a country's economic situation, legislation, fiscal policy, and other factors. Independent budget segments, such as current and investment budgets, imply different sources of funding. The presented method offers a rapid analysis of budget indices, which allows to assess its current stability.

We are convinced that a deeper and more detailed analysis of key budget indicators is necessary to assess the financial condition of regional governments and the sustainability of their budgets. The analysis of the regional budget process should include the following key index blocks.

The analysis of the factors of regional budget stability provides the following indicators for assessing the budget process:

- the ratio of private and regulatory budget revenues:

$$
k_{\sigma}=\frac{D_{\mathrm{x}}}{D_{\mathrm{T}}}
$$

in this era: $k_{6}$ - budget stability ratio;

$D_{\mathrm{x}}$ - private income ratio;

$D_{\mathrm{T}}$ - regulatory revenue ratio.

This ratio shows which part of the budget expenditures falls in favor of the private revenue base.

The relationship between taxable and non-taxable sources is an additional index that assesses the revenue base of the regional budget: 


\section{Comprehensive Assessment of The Regional Potential Investment of The Republic of Uzbekistan}

$$
I_{\mathrm{K}}=\frac{D_{t}}{D_{n T}}
$$

here: $I_{\mathrm{K}}$ - additional index assessing the revenue base of the budget;

$D_{t}$ - taxable income;

$D_{n t}$ - non-taxable income.

This index will be more useful if we do not take into account income that does not represent the result of the tax action of the relevant authority.

Therefore, the ratio of private sector income from taxable income to the value less official transfers is based on international standards of public financial statistics.:

$$
I=\frac{D_{x t}}{D_{n t}-N}
$$

here:

$D_{\mathrm{xt}}$ - private taxable income;

$N$ - official transfers.

$k_{6}, I_{\mathrm{K}}$ and $I$ indices complement each other and describe both sides of the taxable portion of the provincial budget. Discussing the dynamics of these indices allows us to assess the government's performance in mobilizing regional financial potential.

To assess the degree of financial independence of the regional budget, we can use the coefficient of independence:

$$
k_{\mathrm{M}}=\frac{D_{\mathrm{x}}}{\sum_{i=1}^{n} D_{i}}
$$

$D_{\mathrm{x}}$ - private income;

$D_{i}$ - budget revenues.

If the value of this index is high, the financial independence of the regional budget will also be high.

As a quantitative criterion [14], we can use the following scale for these coefficients (Table 1).

Table 1.Territorial budget status criteria [15]

\begin{tabular}{|l|l|l|l|l|l|}
\hline Indices & Stable condition & Normal condition & Moderate condition & Unstable condition & Severe condition \\
\hline Dx:D & $85-100 \%$ & $72-84 \%$ & $60-71 \%$ & $43-59 \%$ & $29-42 \%$ \\
\hline Dт:D & $20-30 \%$ & $40-50 \%$ & $60-70 \%$ & $80-90 \%$ & $90-100 \%$ \\
\hline V:X 6 & $5-10 \%$ & $10-15 \%$ & $20-25 \%$ & $30-35 \%$ & $40-50 \%$ \\
\hline
\end{tabular}

here: $D_{x}$ - private budget revenues;

DT - regulatory revenues;

$D$ - total income;

$X_{\sigma}$ - total budget expenditures;

$\mathrm{V}$ - total budget debts.

II. The effectiveness of the budget policy of the state government is characterized by the budget deficit and the volume of public debt, so it is necessary to assess the state of the regional budget with absolute and relative balance indicators. The budget equilibrium ratio shows how budget expenditures are balanced with revenues:

$$
k_{\mathrm{M}}=\frac{D}{\mathrm{x}_{6}} \cdot 100 \%
$$

III. The following group of indices can be selected to describe the structure of revenues and expenditures of the regional budget:

- Cost structure ratio:

$$
k_{X \text { тар }}=\frac{X_{Ж}}{I_{б}}
$$

here: $X_{Ж}$ - current expenditure budget;

$I_{\sigma}$ - investment budget.

- Private sources guarantee coefficient:

$$
\mathrm{M}_{\mathrm{K}}=\frac{D_{\mathrm{x}}}{\mathrm{X}_{\text {ж}}}
$$

$D_{\mathrm{x}}$ - private income;

$\mathrm{X}_{\text {ж}}$ - current expenses. 


\section{Comprehensive Assessment of The Regional Potential Investment of The Republic of Uzbekistan}

Агар $\mathrm{M}_{\mathrm{K}} \rightarrow 1$ if so, it means that the region can fully cover mandatory costs with revenues from private sources. Using this, the coefficient of the above cost structure can be expressed as follows:

$$
X_{\text {тар }}=\frac{K_{\text {уқм }}}{\mathrm{E}_{\mathrm{p}}}
$$

$\mathrm{K}_{\text {уқм }}$ - long-term and short-term loans;

$\mathrm{S}_{\mathrm{p}}$ - development budget.

If the value of this coefficient is multiple, it indicates a tendency of the budget to lose stability. The generalized level of budget and financial capacity can be determined by the following formula:

$$
\mathrm{b}_{\mathrm{y}}=\frac{D_{\mathrm{x}}+D_{\mathrm{T}}+K}{\mathrm{x}_{6}}
$$

In this formula, $\mathrm{K}$ stands for long-term credit. We determine the investment climate in the regions of the Republic of Uzbekistan based on their specific capabilities and characteristics, using each of the above potential assessment formulas.

\section{ANALYSIS AND RESULTS}

The study found that the change in the share of investments in the regions of the Republic of Uzbekistan was almost imperceptible, and the imbalance has not been eliminated. Of course, the results of this review do not allow for complete information and clear conclusions on the distribution of investments in the regions.

In this sense, from the point of view of the topic, it would be expedient to monitor the distribution of investments in the regions of the country in 2010-2019. To do this, we consider the distribution of investment in the regions according to the law of normal distribution. In this case, the arithmetic mean of the regions for the observed years is determined first, their descriptive analysis is performed, and then the investment distribution is grouped using the Sterdjes formula. (Table 2).

\begin{tabular}{|c|c|c|c|c|c|c|}
\hline \multirow[t]{2}{*}{ № } & \multicolumn{3}{|c|}{ Distribution grouping by accounts } & \multicolumn{2}{|c|}{ Number of regions } & \multirow{2}{*}{$\begin{array}{l}\text { Normative distribution } \\
\%\end{array}$} \\
\hline & $\geq$ & $<$ & " from - to " & Unity & $\%$ & \\
\hline 1 & 2094,60 & 4825,10 & $2094,60-4825,10$ & 7 & $50,0 \%$ & $8,7 \%$ \\
\hline 2 & 4825,10 & 7555,60 & $4825,10-7555,60$ & 5 & $35,7 \%$ & $17,2 \%$ \\
\hline 3 & 7555,60 & 10286,10 & $7555,60-10286,10$ & 1 & $7,1 \%$ & $13,2 \%$ \\
\hline 4 & 10286,10 & 13016,60 & $10286,10-13016,60$ & 0 & $0,0 \%$ & $0 \%$ \\
\hline 5 & 13016,60 & 15747,10 & $13016,60-15747,10$ & 1 & $7,1 \%$ & $13,2 \%$ \\
\hline \multicolumn{4}{|c|}{ Total for all intervals } & 14 & $100 \%$ & $52,3 \%$ \\
\hline \multicolumn{6}{|c|}{ The result of the test of true and normal distributions } & $68 \%$ \\
\hline
\end{tabular}

Table 2.Status of distribution of fixed capital investments by regions (billion soums) ${ }^{1}$

According to the table, the distribution cases were divided into 5 cases ( 1 very bad, 2 bad, 3 medium, 4 good and very good), including 7 regions (Andijan, Jizzakh, Namangan, Samarkand, Syrdarya, Fergana and Khorezm), 5 regions on the 2nd case (Republic of Karakalpakstan, Bukhara, Navoi, Surkhandarya and Tashkent) on the 3rd case in Kashkadarya region. Although in case 4 there are no regions, in case 5 it is possible to observe the city of Tashkent. If we look at the values of normal distribution, in case 1 it is $50.0 \%$ instead of $8.7 \%$, in case 2 it is $17.2 \%$. It was found that $7.1 \%$ were actually distributed instead of $35.2 \%$ and $13.2 \%$ in cases 3-5.

Such a distribution is aimed at the problem of disparities and disparities between the regions "Strong national idea, national program for technological development of Uzbekistan and modernization of the domestic market" 2 puts the task of developing. Of course, the development of such development programs requires an in-depth study and analysis of the individual socioeconomic development of each region of the country.

In this study, the natural-geographical potential of the region can be assessed on the basis of surveys, which we did not take into account in our calculations, as the relationship between them and the obtained statistical data does not allow to synthesize tightly connected neural networks in hybrid networks. Based on the results of the study, it is necessary to further expand the scale of indicators to determine the integral level of investment potential of each region (Figure 1).

\footnotetext{
${ }^{1}$ Source: Author's work based on the data of the State Statistics Committee of the Republic of Uzbekistan

${ }^{2}$ Address of the President of the Republic of Uzbekistan Shavkat Mirziyoyev to the Oliy Majlis. December 22, 2017.
} http://uza.uz/oz/documents 
Completion of indicators to determine the integral level of investment potential

\begin{tabular}{|c|c|}
\hline $\begin{array}{l}\text { Characteristics } \\
\text { of innovative } \\
\text { potential }\end{array}$ & $\begin{array}{l}\text { Number of students in universities, number of organizations engaged in research } \\
\text { and invention, number of employees engaged in research and invention, number } \\
\text { of graduate students, etc.. }\end{array}$ \\
\hline $\begin{array}{l}\text { Budget and } \\
\text { financial } \\
\text { potential }\end{array}$ & $\begin{array}{l}\text { Budget revenues, expenditures, revenues of taxes and other mandatory payments to } \\
\text { the budget, the share of budget revenues in GRP, the share of budget expenditures } \\
\text { in GRP. }\end{array}$ \\
\hline Social potential & $\begin{array}{l}\text { Take into account indicators such as the number of beds in the hospital, the number } \\
\text { of doctors }\end{array}$ \\
\hline $\begin{array}{l}\text { Production and } \\
\text { financial potential }\end{array}$ & $\begin{array}{l}\text { Taking into account the characteristics of individual sectors, in particular, the } \\
\text { total area of the territory and the share of agricultural land in it. }\end{array}$ \\
\hline
\end{tabular}

Figure 1. Completed indicators to determine the integral level of investment potential of the region

In our opinion, the calculation of investment potential should take into account, first of all, innovative potential, as the region's ability to adapt quickly to changing market conditions through the development of new products, production, introduction of new equipment and technologies increases the region's competitiveness. It is then necessary to take into account the budget and financial capacity of the regions, which will determine the rational use and proper distribution of allocated financial resources.

Also, taking into account the budget and financial capacity, the regions characterize the level of independence of a particular entity and its level of subsidies from the budget: the higher the level of independence, the more opportunities to make decisions on financing highly liquid projects for faster movement of financial flows. The low level of independence of the region slows down the distribution of financial resources resulting from the implementation of inter-budgetary relations. Financial resources received by local budgets are redistributed in the State Budget of the Republic of Uzbekistan, and then they are "transferred" to the regional budgets through inter-budgetary transfers. The disadvantages of the subsidy process are the length of time it takes for financial resources to reach regional budgets and the limited funding available.

Of course, specific indicators were selected based on the results of logical and correlation-regression analysis of investment processes in the regions of the country. Given that the integral level of investment attractiveness depends on the size of the population and the size of the regions, the indicators that can be quantitatively assessed per capita, etc. on certain indicators were selected. The results of the calculation of the total level of production and financial potential of the region are given in Table 3.

Table 3.An indicator of the generalized level of production and financial potential of the regions of the Republic of Uzbekistan

\begin{tabular}{|l|l|l|l|l|l|l|l|l|l|}
\hline \multirow{2}{*}{ Regions } & \multicolumn{2}{l}{ Years } \\
\cline { 2 - 10 } & $\mathbf{2 0 1 0}$ & $\mathbf{2 0 1 1}$ & $\mathbf{2 0 1 2}$ & $\mathbf{2 0 1 3}$ & $\mathbf{2 0 1 4}$ & $\mathbf{2 0 1 5}$ & $\mathbf{2 0 1 6}$ & $\mathbf{2 0 1 7}$ & $\mathbf{2 0 1 8}$ \\
\hline Republic of Uzbekistan & 1,0000 & 1,0000 & 1,0000 & 1,0000 & 1,0000 & 1,0000 & 1,0000 & 1,0000 & 1,0000 \\
\hline The Republic of Karakalpakstan & 0,0332 & 0,0496 & 0,0513 & 0,0823 & 0,1112 & 0,1422 & 0,0747 & 0,0795 & 0,0563 \\
\hline Andijon & 0,036 & 0,0453 & 0,0508 & 0,0449 & 0,0404 & 0,0399 & 0,0399 & 0,0359 & 0,0378 \\
\hline Buxoro & 0,1349 & 0,1108 & 0,0999 & 0,1001 & 0,0967 & 0,0928 & 0,1157 & 0,1438 & 0,1011 \\
\hline Jizzax & 0,0235 & 0,0261 & 0,0298 & 0,0353 & 0,0295 & 0,0264 & 0,0251 & 0,036 & 0,0304 \\
\hline Kashkadarya & 0,1102 & 0,1174 & 0,1262 & 0,1219 & 0,1272 & 0,1342 & 0,1416 & 0,1434 & 0,0775 \\
\hline Navoi & 0,1111 & 0,0762 & 0,0713 & 0,0565 & 0,0469 & 0,0404 & 0,0572 & 0,0501 & 0,0751 \\
\hline
\end{tabular}


Comprehensive Assessment of The Regional Potential Investment of The Republic of Uzbekistan

\begin{tabular}{|l|l|l|l|l|l|l|l|l|l|}
\hline Namangan & 0,0352 & 0,0338 & 0,0333 & 0,0369 & 0,0459 & 0,0472 & 0,0516 & 0,0438 & 0,0664 \\
\hline Samarkand & 0,0609 & 0,0638 & 0,0607 & 0,0667 & 0,0638 & 0,0685 & 0,0667 & 0,0591 & 0,0535 \\
\hline Surxondaryo & 0,0371 & 0,038 & 0,0371 & 0,0435 & 0,038 & 0,0392 & 0,0403 & 0,0457 & 0,1084 \\
\hline Sirdaryo & 0,025 & 0,0315 & 0,0276 & 0,0282 & 0,0263 & 0,024 & 0,0249 & 0,0273 & 0,0201 \\
\hline Tashkent & 0,0985 & 0,1167 & 0,0821 & 0,104 & 0,1062 & 0,0973 & 0,0796 & 0,0676 & 0,1055 \\
\hline Fergana & 0,0554 & 0,0642 & 0,061 & 0,0662 & 0,0567 & 0,0512 & 0,0483 & 0,0463 & 0,0464 \\
\hline Khorezm & 0,0233 & 0,0304 & 0,0307 & 0,04 & 0,0416 & 0,0322 & 0,029 & 0,0271 & 0,0278 \\
\hline Tashkent & 0,2157 & 0,1962 & 0,2383 & 0,1735 & 0,1694 & 0,1645 & 0,2054 & 0,1943 & 0,1938 \\
\hline
\end{tabular}

According to the calculations, Bukhara (0.996), Kashkadarya (1.1), Navoi (0.59), Samarkand (0.56), Tashkent (0.86) regions and the city of Tashkent (1.75) were developed. output and financial potential are above average. According to the calculations, the city of Tashkent and Kashkadarya region have a high production and financial potential, which is due to the high level of industrial production in its territory. However, in recent years, the production and financial potential of the Republic of Karakalpakstan and Kashkadarya region has been declining, primarily due to the bankruptcy of industrial enterprises and the reorganization of industrial enterprises, the volume of industrial production has decreased. A number of indicators are also used to calculate the integral level of social potential of the regions (Figure 2).

Indicators for calculating the integral level of social potential of regions

Number of employees engaged in research and development and the share of economically active population in the total population;

The number of academic staff per 1,000 population and the number of university students per 10,000 population;

The share of farms in the economically active population and the number of homeowners' associations;

The number of public organizations and the number of individual entrepreneurs per 10000 people;

Costs of information and communication technologies per 1000 population of the region and the number of defended candidate and doctoral dissertations;

Patent applications for inventions and utility models and patents for those models;

The volume of innovative goods, works, services as a percentage of the total volume of shipped, performed and rendered services;

Labor costs of the creative class of the population and the number of advanced technologies created;

The volume of products produced by small entrepreneurs and farms, as well as the gross regional product per capita.

Figure 2. Indicators for calculating the integral level of social potential of regions 


\section{Comprehensive Assessment of The Regional Potential Investment of The Republic of Uzbekistan}

Thus, all stages of the process of typology of regions in the area under consideration in this study have passed in sequence. First, a system of human potential indicators was formed, which led to the substantiation of a system of indicators consisting of 53 indicators for 14 objects and a correlation analysis of 18 indicators. This system includes 3 economic and 7 social indicators that characterize human potential.

Second, a cluster analysis was conducted, which divided all regions into 5 groups. The study was conducted in two ways: with and without economic indicators. As a result of the analysis of data obtained over 10 years, a stable typology of the regions of the Republic of Uzbekistan on the basis of human potential indicators is built.

Third, a meaningful interpretation of the results is given. Systematization of regions by cluster allows us to see their main problems and achievements in terms of population quality (Table 4).

Table 4.Generalized indicator of the social potential of the regions of the Republic of Uzbekistan

\begin{tabular}{|c|c|c|c|c|c|c|c|c|c|}
\hline \multirow{2}{*}{ Regions } & \multicolumn{9}{|l|}{ Years } \\
\hline & 2010 & 2011 & 2012 & 2013 & 2014 & 2015 & 2016 & 2017 & 2018 \\
\hline Republic of Uzbekistan & 1,00 & 1,00 & 1,00 & 1,00 & 1,00 & 1,00 & 1,00 & 1,00 & 1,00 \\
\hline The Republic of Karakalpakstan & 0,37 & 0,43 & 0,47 & 0,50 & 0,54 & 0,58 & 0,64 & 0,72 & 0,77 \\
\hline Andijon & 0,32 & 0,37 & 0,44 & 0,49 & 0,57 & 0,64 & 0,68 & 0,72 & 0,76 \\
\hline Buxoro & 0,50 & 0,56 & 0,59 & 0,67 & 0,74 & 0,78 & 0,82 & 0,85 & 0,88 \\
\hline Jizzax & 0,28 & 0,32 & 0,37 & 0,45 & 0,48 & 0,50 & 0,56 & 0,58 & 0,61 \\
\hline Kashkadarya & 0,34 & 0,36 & 0,38 & 0,43 & 0,46 & 0,51 & 0,55 & 0,57 & 0,65 \\
\hline Navoi & 0,35 & 0,98 & 0,34 & 0,38 & 0,19 & 0,46 & 0,79 & 0,63 & 0,74 \\
\hline Namangan & 0,44 & 0,49 & 0,53 & 0,57 & 0,63 & 0,67 & 0,69 & 0,72 & 0,76 \\
\hline Samarkand & 0,61 & 0,57 & 0,62 & 0,67 & 0,71 & 0,74 & 0,77 & 0,79 & 0,86 \\
\hline Surxondaryo & 0,29 & 0,37 & 0,39 & 0,43 & 0,47 & 0,49 & 0,54 & 0,59 & 0,65 \\
\hline Sirdaryo & 0,25 & 0,36 & 0,38 & 0,41 & 0,45 & 0,48 & 0,54 & 0,59 & 0,64 \\
\hline Tashkent & 0,20 & 0,35 & 0,43 & 0,46 & 0,51 & 0,53 & 0,55 & 0,57 & 0,60 \\
\hline Fergana & 0,44 & 0,46 & 0,48 & 0,52 & 0,55 & 0,59 & 0,62 & 0,65 & 0,73 \\
\hline Khorezm & 0,46 & 0,48 & 0,52 & 0,56 & 0,58 & 0,62 & 0,69 & 0,72 & 0,74 \\
\hline Tashkent & 0,64 & 0,67 & 0,69 & 0,72 & 0,77 & 0,79 & 0,83 & 0,87 & 0,89 \\
\hline
\end{tabular}

Based on the data in the table, the correlation was grouped into clusters according to the density level as follows:

Cluster 1: very high (0.800-1.00); Cluster 2: high (0.700-0.799)

Cluster 3: medium (0.555-0.699); 4-cluster: past (0.350-0.554)

Cluster 5: very low (0.200-0.349).

According to the results of the calculation, the Republic of Uzbekistan and its territories Tashkent (0.763), Samarkand (0.704) and Bukhara (0.700) are included in the 2nd cluster, ie the highest level, the 3rd cluster is the Republic of Karakalpakstan (0.558), Andijan (0.556), Namangan (0.611). , Fergana (0.560) and Khorezm (0.597) regions, and the 4th cluster includes Jizzakh (0.461), Kashkadarya (0.477), Navoi (0.517), Surkhandarya (0.469), Syrdarya (0.456) and Tashkent (0.406) regions.

This phase of the work, in turn, can be seen as the beginning of a new scientific study that answers the question of ways and means of overcoming regional inequality in human potential indicators. Apparently, these methods can be linked to clusters, which significantly reduces and simplifies the system of measures to help reduce the regional stratification of human potential indicators.

Now, the innovation potential of the regions can be further determined by assessing the importance of the group indicators on the results of the index (3) - (5) using expert assessments based on the above method social tools (Table 5).

Table 5. An indicator of the generalized level of innovation potential of the regions

\begin{tabular}{|l|l|l|}
\hline Clusters & Criteria boundaries & Regions \\
\hline 1-cluster & $3-3,5$ & Tashkent city \\
\hline 2-cluster & $2,50-2,99$ & Andijan, Samarkand, Khorezm \\
\hline 3-cluster & $2,0-2,49$ & Republic of Karakalpakstan, Bukhara, Namangan, Tashkent \\
\hline
\end{tabular}


Comprehensive Assessment of The Regional Potential Investment of The Republic of Uzbekistan

\begin{tabular}{|l|l|l|}
\hline 4-cluster & $1,50-1,99$ & Jizzakh, Kashkadarya, Navoi, \\
\hline 5-cluster & $1,0-1,49$ & Surkhandarya, Syrdarya, Fergana \\
\hline
\end{tabular}

The innovative potential of the city of Tashkent took 1st place, which was due to many different educational institutions, research institutions and many students in the region. The innovative potential of Surkhandarya, Syrdarya and Fergana regions is in the last place and corresponds to the 5th cluster, ie at a very low level. The overall level of innovation potential of these regions is much lower than in Tashkent, which is mainly due to the large rural population, low level of creation and production of new products. In general, the dynamics of innovation potential is growing in the regions of the Republic of Uzbekistan.

On the basis of indicators for the assessment of innovative potential, it is possible to identify the problems of growth and resources of the regional economy. In fact, in the context of the formation of new economic relations, it is necessary to develop an innovative environment, the rational use of resources, taking into account the specifics of development, the direction of state policy in the field of innovative development for each region.

At the next stage, the results of the calculation of the generalized level of budget and financial potential of the regions of the Republic of Uzbekistan on the basis of the above formulas (6) - (14) are given in Table 6.

Table 6.Indicators of the generalized level of budget and financial potential of the regions of the Republic of Uzbekistan

\begin{tabular}{|l|l|l|l|l|l|l|l|l|l|}
\hline \multirow{2}{*}{ Regions } & \multicolumn{2}{|l|}{ Years } \\
\cline { 2 - 10 } & $\mathbf{2 0 1 0}$ & $\mathbf{2 0 1 1}$ & $\mathbf{2 0 1 2}$ & $\mathbf{2 0 1 3}$ & $\mathbf{2 0 1 4}$ & $\mathbf{2 0 1 5}$ & $\mathbf{2 0 1 6}$ & $\mathbf{2 0 1 7}$ & $\mathbf{2 0 1 8}$ \\
\hline Republic of Uzbekistan & 1,00 & 1,00 & 1,00 & 1,00 & 1,00 & 1,00 & 1,00 & 1,00 & 1,00 \\
\hline The Republic of Karakalpakstan & 0,28 & 0,29 & 0,29 & 0,31 & 0,31 & 0,32 & 0,33 & 0,34 & 0,35 \\
\hline Andijon & 0,29 & 0,30 & 0,31 & 0,32 & 0,33 & 0,34 & 0,34 & 0,35 & 0,36 \\
\hline Buxoro & 0,19 & 0,22 & 0,23 & 0,23 & 0,25 & 0,25 & 0,26 & 0,27 & 0,28 \\
\hline Jizzax & 0,21 & 0,22 & 0,23 & 0,23 & 0,24 & 0,25 & 0,30 & 0,31 & 0,39 \\
\hline Kashkadarya & 0,17 & 0,18 & 0,19 & 0,20 & 0,21 & 0,22 & 0,28 & 0,29 & 0,30 \\
\hline Navoi & 0,25 & 0,26 & 0,27 & 0,28 & 0,30 & 0,31 & 0,32 & 0,33 & 0,34 \\
\hline Namangan & 0,26 & 0,29 & 0,30 & 0,31 & 0,32 & 0,34 & 0,34 & 0,35 & 0,35 \\
\hline Samarkand & 0,28 & 0,28 & 0,29 & 0,31 & 0,32 & 0,33 & 0,33 & 0,34 & 0,36 \\
\hline Surxondaryo & 0,17 & 0,17 & 0,18 & 0,17 & 0,18 & 0,20 & 0,22 & 0,22 & 0,25 \\
\hline Sirdaryo & 0,16 & 0,18 & 0,18 & 0,17 & 0,18 & 0,19 & 0,21 & 0,22 & 0,23 \\
\hline Tashkent & 0,24 & 0,25 & 0,26 & 0,27 & 0,28 & 0,29 & 0,30 & 0,32 & 0,33 \\
\hline Fergana & 0,21 & 0,24 & 0,24 & 0,25 & 0,26 & 0,28 & 0,29 & 0,31 & 0,31 \\
\hline Khorezm & 0,28 & 0,29 & 0,24 & 0,25 & 0,26 & 0,27 & 0,26 & 0,28 & 0,29 \\
\hline Tashkent & 0,32 & 0,33 & 0,35 & 0,39 & 0,40 & 0,41 & 0,42 & 0,43 & 0,44 \\
\hline
\end{tabular}

Thus, the first place in terms of budget and financial potential is occupied by the city of Tashkent. This is, first of all, due to the high level of income coming to the budget due to the development of large-scale industrial production in the region, the development of trade. Samarkand region took the second place, Andijan region the third, and Tashkent region the budget and financial potential took the fifth place.

A change in the above coefficients means an improvement or deterioration in the financial condition of the region. If the index approaches the index, the financial base of the region will work stably. This index reflects the sustainability of the regional budget and economic development in general (Table 7).

Table 7.Distribution of the territories of the Republic of Uzbekistan according to the criteria of the situation

\begin{tabular}{|l|l|l|}
\hline Circumstances & Criteria & Regions \\
\hline Stable condition & $85-100 \%$ & Tashkent city \\
\hline Normal condition & $72-84 \%$ & $\begin{array}{l}\text { The Republic of Karakalpakstan, Andijan, Navoi, } \\
\text { Namangan, Samarkand and Tashkent regions }\end{array}$ \\
\hline Moderate condition & $60-71 \%$ & Bukhara, Jizzakh, Fergana, Khorezm \\
\hline Unstable condition & $43-59 \%$ & Kashkadarya, Surkhandarya, Syrdarya, \\
\hline Severe condition & $29-42 \%$ & - \\
\hline
\end{tabular}




\section{Comprehensive Assessment of The Regional Potential Investment of The Republic of Uzbekistan}

As can be seen from the table data. Only the financial and budgetary potential of the city of Tashkent in the Republic of Uzbekistan is stable, and in the Republic of Karakalpakstan, Andijan, Navoi, Namangan, Samarkand and Tashkent regions it is normal. No serious situation with the use of the budget was observed in the regions of the Republic of Uzbekistan. This indicates that the policy of the fiscal system in the regions is satisfactory. These indicators determine the financial and budgetary system of the region, its economic system, the profitability of industries, the efficiency of development and production of regional enterprises. In the context of unstable global and regional economic processes, it is possible to assess the direction of financial and economic development of the region with the help of the financial development index against the background of the crisis.

\section{DISCUSSION}

According to the calculations on the use of investment attractiveness of the regions, the city of Tashkent, Samarkand and Andijan regions are effectively using their investment potential and investment attractiveness. It should be noted that in other regions of the country the investment potential is not fully used and their use is lower than the national average. As for Jizzakh, Syrdarya and Surkhandarya regions, the investment potential and investment attractiveness of the region are being used inefficiently. Therefore, it is necessary for the regional government to organize effective investment activity management, taking into account the existing opportunities to attract investors and, first of all, to create a favorable investment climate to attract investment to the region.

At the same time, it is necessary to know the composition of the proposed system for measuring the investment climate, the correct choice of factors and the correct use of tools to determine the investment attractiveness of the regions.

\section{CONCLUSION/RECOMMENDATIONS}

In conclusion, the methodological basis of the analysis of regional development is that the region is not a strictly autonomous object, but a multifunctional region developing on the basis of vertical (central-regional) and horizontal (interregional) interdependence included in the system of world economic relations. It should be noted that the analysis and forecasting of the distribution of investments in the economic development of the regions should be created as interconnected backbone structures, which should become a common strategy of socio-economic development of the country.

Based on the above-mentioned results, it is also important to know the criteria and indicators of socio-economic growth in order to increase the efficiency of investment in the production process, to have a clear idea of what factors and how they are related. It is advisable to resort directly to mathematical tools to analyze the above data in general. This, of course, requires the study of modeling processes, understanding and conclusions about mathematical formulas, which provide for the interrelationships, interrelationships and connections of the given statistical data.

It should be noted that the large number of selected factors requires their study into specific classes and generalization. In this case, the method of dividing the sample into groups of objects that do not intersect, based on the fact that the objects are connected, based on the definition of the subset of classes boundary objects. In this case, it is advisable to cover the sample with reference objects from grouping.

In summary, the application of neural models in practice to the implementation of regional distribution of investments, as in other sectors, allows to make clear decisions for this process, as well as to identify hidden patterns in the process, to make clear decisions in uncertainty. However, neural networks are not the only method, and in many cases the application of traditional statistical methods is more effective. However, in many areas of risk management, neural networks find a more sensible solution and require further research in this area.

\section{REFERENCE}

1) Samuel Björklund, Tobias Uhlin Artificial neural networks for financial time series prediction and portfolio optimization. ISRN: LIU-IEI-TEK-A-17/02920-SE, 2017.-173 p.;

2) Kohonen, T. 1988a. Learning vector quantization. Neural Networks 1, suppl. 1, 303.;

3) Howard B Demuth, Mark H Beale; Neural Network Design (2nd Edition), 2014, -800 p.;

4) Samuelson Paul A. Risk and Uncertainty: A Fallacy of Large Numbers. Scented, 1997;

5) Шарп У, Александер Г, Бейли Дж., Инвестиции: Пер.сангл. - М.: Инфра-М, 2010. - 1028 с;

6) Лоренс Дж.Гитман, Майкл Д.Джонк. Основы инвестирования. М.:«Дело», 2007, с-10;

7) Макконнел К.Р., БрюС.Л. Экономикс: принципы, проблемы и политика. 2-том. М.:Республика, 2002, с-338;

8) Зайченко Ю.П. Нечеткие модели и методи в интеллектуальных системах. - К.: Видавничий Дим «Слово», 2008. - 352 c.; 


\section{Comprehensive Assessment of The Regional Potential Investment of The Republic of Uzbekistan}

9) Батыршин И.3. Нечеткие гибридные системы. Теория и практика / Под ред. Н.Г. Ярушкиной. - М. Физматлит, 2007. -208 с.;

10) Аксенов С.В., Новосельцев В.Б. Организация и использование нейронных сетей (методы и технологии) / Под общ. ред. В.Б. Новосельцева. - Томск: Изд-во НТЛ, 2006. - 128 с.;

11) Круглов В.В., Борисов В.В. Искусственные нейронные сети. Теория и практика. -2-е изд. стереотип. -М.: Горячая линия-Телеком, 2002. -382 с;

12) Нейронные сети в прикладной экономике: Е.А. Трофимова, Вл.Д. Мазуров, Д.В. Гилёв; [под общ. ред. Е.А. Трофимовой]; Барский А. Б. Нейронные сети: распознавание, управление, принятие решений. - М.: Финансы и статистика, 2004. - 176 с.

13) И.Гришина Методология комплексного анализа инвестиционных процессов в регионах России / И. Гришина // Инвестиции в России. - 2005. - № 4. - С. 3-10.

14) G.B. Polyak, (Ed.), Budgetary system of Russia (UNITY, Moscow,1999)

15) Vladimer Glontil,*, Miras Zhiyenbayev and Rezo Manvelidze The method of estimating the regional budgetary process.// MATEC Web of Conferences 212, 08029 (2018) https://doi.org/10.1051/matecconf/201821208029 ICRE 2018.

16) O Umid. Theoretical and methodical bases of the securities instrument application in the modernization and diversification conditions of the economy. // Science and Practice Bulletin, №7 (20), - M.: « Science and practice» 2017.

17) UA Otajanov. Methods of distribution regularity in allotment of the regional investments. Scientific developments: The Eurasian region: materials of the international scientific conference of theoretical and applied developments (January 30 , 2019). - M: Infinity Publishing, 2019, pp 63-69.

18) O.U. Abdullaevich. The main aspects of innovative development regions of the Republic of Uzbekistan. Journal of Process Management. New Technologies. №7(1), 2019, стр. 78-85 